\title{
DESIGN OF HEAT-RECOVERY AND SEED-RECOVERY UNITS IN NID POWER GENERATION
}

P.D. Bergman, J.I. Joubert, R.J. Demski, and D. Bienstock

U.S. Department of the Interior, Bureau of Mines, Pittsburgh Energy Research Center, Pittsburgh, Permsylvania

\section{Abstract}

Crucial and limiting engineering and materials problems associated with the design of an MHD steam bottoming plant are discussed. Existing experimental and theoretical results on corrosion, fouling and deposits, potassium seed recovery and regeneration, are reviewed. The state of knowledge regarding the design of heat recovery and seed recovery units for coal-fired MHD plants is inadequate at the present time.

\section{Introduction}

A successful design of the heat recovery and seed recovery portions of a projected coal-fired $\mathrm{MHD}$ power plant will require the solution of several unique and challenging materials problems. These problens lie in the areas of corrosion, fouling and deposits, seed recovery, and seed regeneration. Corrosion and deposit formation are familiar areas nf concern to the boilar

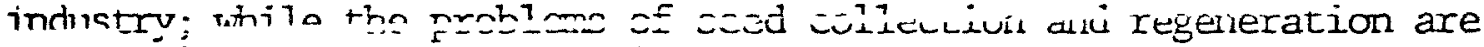
essentially new problems peculiar to MHD technology.

Fouling of tubes, blockage of equipment passages, destruction of metal and refractory heat transfer surfaces, heavy losses of alkali seed into coal slag, and the inability to remove and regenerate the spent MHD seed, can have severe operational and economic consequences. A number of individuals with experience in the utility industry have expressed serious reservations about the ability of MHD researchers to sumount these problems $(12,23)$. This paper discusses these problems and describes relevant Bureau of Mines experience in these areas.

\section{Downstream Environment}

Initially, we will seek to partially characterize the type of downstream enviroment to which candidate metals and refractories will be exposed. Fig. 1 displays a set of typical operating temperatures prevailing in various downstream components for both a separately and directly fired MD powerplant. One mode of operation, which currently $(2,18)$ is receiving serious consideration, is combustion of coal with $95 \%$ stoichionetric air, with an additional $6 \%$ introduced downstrem in the superheat or reheat sections of the steam plant, in.order to corplete combustion. This procedure is carried out to reduce plant $\mathrm{NO}_{\mathrm{x}}$ levels.

\section{ROTICE}

PORTIONS OF THIS REPORT ARE IITEGIBIE. It has been reproduced from the best available copy to permit the broadest possible availAhilitv.
- MASTER

oistribution of this mocument is unLmited

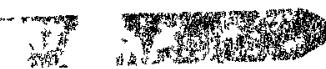




\section{DISCLAIMER}

This report was prepared as an account of work sponsored by an agency of the United States Government. Neither the United States Government nor any agency Thereof, nor any of their employees, makes any warranty, express or implied, or assumes any legal liability or responsibility for the accuracy, completeness, or usefulness of any information, apparatus, product, or process disclosed, or represents that its use would not infringe privately owned rights. Reference herein to any specific commercial product, process, or service by trade name, trademark, manufacturer, or otherwise does not necessarily constitute or imply its endorsement, recommendation, or favoring by the United States Government or any agency thereof. The views and opinions of authors expressed herein do not necessarily state or reflect those of the United States Government or any agency thereof. 


\section{DISCLAIMER}

Portions of this document may be illegible in electronic image products. Images are produced from the best available original document. 
As the MHD combustion plasma cools, a mmber of significant phase changes and chemical reactions take place. Within the $M \mathbb{H} D$ channel itself, molten coal slag condenses out of the MDD combustion gas, leading to the formation of a slag coating on the generator electrodes and insulators. At cooler downstream locations, molten slag and solid fly ash deposit out on the walls of the various components, as the gas phase is progressively depleted of its ash constituents. The composition of molten coal slag varies with temperature as a result of the differing volatilities of the various slag constituents. Each operating temperature range corresponds to a somewhat different slag enviroment. The portion of the coal ash winich does not condense or freeze on component surfaces is blown through the system and ultimately collected as solid fly ash.

Unfortmately, the potassium MHD seed also reacts with coal slag to form insoluble potassium-alunimm-silicon-oxygen compormds. This fact has been verified both experimentally and theoretically $(2,20,21)$. This reaction cammences at temperatures encountered in the MHD chamel and continues until substantial quantities of potassium are captured by the molten slag. Any seed trapped in such a manmer has proved impossible to recover using conventional hot water extraction techiques. Fresh MHD seed must then be added to the combustor to conpensate for this loss. However, below $1500 \% \mathrm{~K}$ a mixture of soluble potassium salts $\left(\mathrm{K}_{2} \mathrm{CO}_{3}, \mathrm{~K}_{2} \mathrm{SO}_{4}, \mathrm{~K}_{2} \mathrm{~S}\right.$, etc.) condenses out of the MHD exhaust gas. Fortumately, these salts are sisceptible to recovery by hot water extraction.

At still cooler temperatures, the seed phase freezes, which would tend to prevent the corrosive attack on materials by the molten salt mixture. The seed phase, itself, is a rather complex mixture of potassium compounds. However, in many instances, two components may be dominant. Probably the three most carmon mixtures will be $\mathrm{K}_{2} \mathrm{~S}-\mathrm{K}_{2} \mathrm{CO}_{3}, \mathrm{~K}_{2} \mathrm{CO}_{3}-\mathrm{K}_{2} \mathrm{SO}_{4}$ and $\mathrm{K}_{2} \mathrm{~S}-\mathrm{K}_{2} \mathrm{SO}_{4}$. The prevalence of these mixtures are dependent on the fuel:air ratio. Phase diagrams for these systems are available $(9,17,20)$. Freezing points as high as $1070^{\circ} \mathrm{C}$ and as low as $600^{\circ} \mathrm{C}$ have been reported.

Therefore, it becones apparent that a knowledge of phase distributions and comositions within the downstream plant system is extremely important. The USBM High-Temperature Chenical Equilibrium Program (22), developed for the calculation of the chemical compositions and thermodynamic properties of complex multiphase equilibrium mixtures, has been employed to predict trends in these areas. It should be realized that the results of this program are dependent on the accuracy and availability of data from standard sources such as the JANAF Tables.

The following figures provide a few illustrations of its capabilities. Fig. 2 indicates the shift in composition with temperature of a typical potassiumcontaining MHD coal slag. For example, it is clear that the kind of slag forming in the MHD diffuser will be different from that forming in the lowtemperature air heater. Fig. 3 displays the depletion of potassium from the gas phase on cooling, followed by an increase of potassium in the molten slag phase and finally, the development of a soluble seed phase. Fig. 4 illustrates 
the importance of high slag rejection in the MHD combustor in lowering the loss of potassium into molten coal slag. Fig. 5 indicates the effect of reduced air operation on potassium compound formation. $\mathrm{K}_{2} \mathrm{~S}$ becomes quite prevalent as the air level is reduced; while $\mathrm{K}_{2} \mathrm{SO}_{4}$ is the dominant compound for operation with excess air. This fact becomes important in $M H D$ seed regeneration, where the conversion of $\mathrm{K}_{2} \mathrm{SO}_{4}$ to $\mathrm{K}_{2} \mathrm{~S}$ demands the expenditure of a considerable quantity of energy.

The composition of actual wall deposits at a particular temperature depends upon fluid mechanical, heat transfer, and mass transfer considerations which are beyond the scope of this equilibrium model. However, the equilibrium program does provide a valauble guide as to what phenonena may be reasonably anticipated in the MHD-steam bottaming plant. For example, Spencer (21) has successfully correlated the predictions of this model with experimental data. on potassium seed losses into slag, previously acquired from operation of the USBM pilot combustion facility. In summation, more basic information on component themodynamics and phase behavior is urgently required to establish a firmer scientific basis for resolving the critical problems of corrosion, deposits, and seed recovery.

\section{Corrosion}

The problen of fireside corrosion of boiler and simerheater tuhes has had a piuíumi mpact on existing conventional steam plant construction. From 1930 owwards, maximum steam operating temperatures have been pushed continuously upwards from $850^{\circ} \mathrm{F}$ (4540 C). By the mid-1950's, steam temperatimes had ascended as high as $1200{ }^{\circ} \mathrm{F}\left(649^{\circ} \mathrm{C}\right)$ in the Eddystone power plant of the Philadelphia Electric Company (19). Severe metal wastage by conrosive deposits was experienced in the high temperature zones of a number of units in the Eddystone plant (16). These deposits were related to the formation of complex alkali sulfates at $1050^{\circ} \mathrm{F}\left(566^{\circ} \mathrm{C}\right)$. As a result of this experience, design steam temperatures for utility boilers were lowered and have remained relatively static at $1000^{\circ} \mathrm{F}\left(538^{\circ} \mathrm{C}\right)$.

- Metals in an MHD enviroment will face an extremely severe test because of the presence of high concentrations of alkali and sulfur. Alkali and sulfur in a fuel have been regarded as precursors of corrosion and deposit problems. Michel and Wilcoxson(15) found that alkali addition to a low alkali coal leads to increased fouling of superheater tubes. - The presence of sulfur leads to $\mathrm{SO}_{3}$ and complex sulfate formation; both of which are directly involved in corrosion reactions (19). undertaken.

Only a limited amount of corrosioñ rèsearch related to MID has been $\because$

British workers (11) studied a number of representative superheater metals under oil-fired MHD conditions. Air-cooled tubular specimens were exposed to flue gases from a gas-oil burner at metal temperatures of 400-650年 $\left(752-1202^{\circ} \mathrm{F}\right)$. Because of their interest in oil-fired MHD, vanadium and sodium were added to the fuel. Additional $\mathrm{SO}_{2}$ was also added to yield $2000 \mathrm{ppm}$ of $\mathrm{SO}_{2}$ in the flue gas. 
The tests were for periods of 70,250 , and 1000 horrs at a seeding level of 0.01 atom $\% \mathrm{~K}$. It was realized that this seeding level was substantially less than that to be expected in comnercial MHD operations. However, earlier studies had shown that the deposit composition on metal surfaces was independent of seed level and that the rate of corrosion was not affected by the amount of deposit.

An average corrosion rate of 50 nanometers/hr was taken to indicate that a material was acceptable for plant use. It was found that corrosion rates were, in general, far above the acceptable level for potential superheater metal temperatures of $547-597^{\circ} \mathrm{C}(1012-11070 \mathrm{~F})$. Only one steel, $60 \mathrm{Cr} / 40 \mathrm{Ni}$, was found to be suitable for temperatures up to $597^{\circ} \mathrm{C}$ (11070F). Because of the cost and low crrep strength of this steel, it was concluded that it could only be used as a coating or shielding material.

Corrosion rates at 250 hours were lower than those measured over 70 hours. In some cases, the rates measured over 1000 hours were still lower. Despite this, the conclusions regarding the suitability of the metals studied remained unaltered.

In same of the 70 hour tests, no vanadium was added to the fuel. This only resulted in about a 50\% reauction in corrosion rates wich still placed the materiais tostad (excent $60 \mathrm{Cr} / 40 \mathrm{Mi}$ ) cutside the range of accepcability.

Hals, Keefe, and El Bindari (10) studied corrosion of various steels and high-temperature alloys used in boiler tubes and conventional heat exchangers. An MHD atmosphere was sirmlated by injecting synthetic coal ash, sulfur, and potassium salts $\left(\mathrm{K}_{2} \mathrm{OO}_{3}\right.$ or $\left.\mathrm{K}_{2} \mathrm{SO}_{4}\right)$ into the combustion procucts of a natural gas/enriched air mixture. The seed level of the resulting plasma was 0.2 mole-\% potassium. Tube metal temperatures were controlled between $350 \% \mathrm{~F}$ $(1770 \mathrm{C})$ and $1760^{\circ} \mathrm{F}(9600 \mathrm{C})$.

Severe corrosion after 100 hours and tube failures after 200 horrs were experienced at tube-metal temperatures above $1550^{\circ} \mathrm{F}\left(843^{\circ} \mathrm{C}\right.$ ). The corrosion was attributed to formation of liquid mixtures of $\mathrm{K}_{2} \mathrm{SO}_{4}-\mathrm{Na}_{2} \mathrm{SO}_{4}$, a system which exhibited a minimm melting point of $15300 \mathrm{~F}\left(822^{\circ} \mathrm{C}\right)$. The molten sulfates attacked the iron and nickel in the tubes to form the sulfides, releasing

alkali oxides into the gas phase to again form alkali sulfates by reaction with $\mathrm{SO}_{2}$ and $\mathrm{O}_{2}$.

No metal corrosion was observed at temperatures below $1530^{\circ} \mathrm{F}\left(822^{\circ} \mathrm{C}\right)$. In particular, no corrosion was experienced by formation of complex alkali sulfates or pyrosulfates which have been reported to cause severe corrosion $\because$ of superhcater and reheater tubes at metal temperatures of $1025-1300^{\circ} \mathrm{F}$

$=\left(550-704^{\circ} \mathrm{C}\right)$, and of furnace wall tubes at $600-700^{\circ} \mathrm{F}\left(311-371^{\circ} \mathrm{C}\right)$ in coalfired boilers. That no such corrosion occurred was attributed to the umique operating conditions of an NMD system; i.e., near-stoichionetric combustion, high conbustion temperature, rapid cooling, and uniform gases tend to suppress $\mathrm{SO}_{3}$ formation, which is a factor in formation of the pyrosulfates and complex alkali sulfates. 
The Bureau of Mines investigated the corrosion characteristics of various boiler tube metals in a coal-fired combustion system (3). A cyclone combustor was built that was capable of burning $125 \mathrm{lbs} / \mathrm{hr}$ of coal and producing flame temperatures of $4000^{\circ} \mathrm{F}\left(2204^{\circ} \mathrm{C}\right)$. Ten different metals and alloys were studied ranging from inexpensive carbon steel to very expensive Haynes 25 (a high cobalt alloy). These results are reported in Table 1.

TABLE 1. - Metal Loss of Corrosion Specinens in Combustion Gas With Unseeded Coal and in Combustion Gas with Coal

- Seeded With Potassium Carbonate

\begin{tabular}{|c|c|c|c|c|}
\hline Material & $\begin{array}{l}\text { Metal } \\
\text { temp. } \\
\mathrm{O}_{\mathrm{F}}\end{array}$ & $\begin{array}{c}\text { Flue gas } \\
\text { terp., } \\
\text { o. }\end{array}$ & $\begin{array}{l}\text { Metal loss } \\
\text { while burning } \\
\text { unseeded coal, } \\
\text { inches }\end{array}$ & $\begin{array}{l}\text { Metal loss } \\
\text { while buning } \\
\text { seeded coal, } \\
\text { inches }\end{array}$ \\
\hline $\begin{array}{l}\text { Carbon steel (A 106) } \\
\text { Croloy } 2 \frac{1}{4} \\
\text { Croloy } 5\end{array}$ & $\begin{array}{l}800 \\
800 \\
800\end{array}$ & $\begin{array}{l}1800 \\
1800 \\
1800\end{array}$ & $\begin{array}{l}(1) \\
0.0000 \\
0.0025\end{array}$ & $\begin{array}{l}0.0075 \\
0.0015 \\
0.0075\end{array}$ \\
\hline $\begin{array}{l}446 \text { Stainless steel } \\
406 \text { Stainless steel } \\
316 \text { Stainless ateel } \\
310 \text { Stainicss steei }\end{array}$ & $\begin{array}{l}1100 \\
1100 \\
1100 \\
i 1 \overline{0}\end{array}$ & $\begin{array}{l}2100 \\
2100 \\
2100 \\
2100\end{array}$ & $\begin{array}{l}0.0000 \\
0.0055 \\
0.0000 \\
0.0000\end{array}$ & $\begin{array}{l}0.0000 \\
0.0035 \\
0.0000 \\
0.0000\end{array}$ \\
\hline $\begin{array}{l}310 \text { Stainless steel } \\
\text { Nickel } \\
\text { Inconel } \\
\text { Haynes } 25\end{array}$ & $\begin{array}{l}1500 \\
1500 \\
1500 \\
1500\end{array}$ & $\begin{array}{l}2500 \\
2500 \\
2500 \\
2500\end{array}$ & $\begin{array}{l}0.0015 \\
0.0035 \\
0.0000 \\
\quad(1)\end{array}$ & $\begin{array}{c}(2) \\
(2) \\
(2) \\
0.0005\end{array}$ \\
\hline \multicolumn{4}{|c|}{$\begin{array}{l}\text { (1) Cooling air failure caused loss of specimen. } \\
\text { (2) Completely oxidized after } 50 \text { hours. }\end{array}$} & - \\
\hline
\end{tabular}

Test samples were located at various points in a refractory-lined tower following the combustor. Metal surface temperatures of $1500^{\circ} \mathrm{F}\left(816^{\circ} \mathrm{C}\right)$, $1100^{\circ} \mathrm{F}\left(593^{\circ} \mathrm{C}\right)$, and $800^{\circ} \mathrm{F}\left(427^{\circ} \mathrm{C}\right)$ were maintained by air flow through the tube specimens. Flue gas temperatures corresponding to these surface temperatures were $2500^{\circ} \mathrm{F}\left(1371^{\circ} \mathrm{C}\right), 2100^{\circ} \mathrm{F}\left(1149^{\circ} \mathrm{C}\right)$, and $1800^{\circ} \mathrm{F}\left(982^{\circ} \mathrm{C}\right)$, respectively. The design velocity of the gas through the tubes was $80 \mathrm{ft} / \mathrm{sec}$.

In one experiment, coal containing $4.4 \% \mathrm{~K}_{2} \mathrm{CO}_{3}$ was bumed over a 100 hour period at $105 \%$ of stoichiometric conditions. The results were compared with those of a similar experiment in which unseeded coal was used. The specimens exposed to the potassium-containing flue gas were more severely attacked than those exposed to the flue gas of the unseeded coal. 
At metal temperatures of $1500^{\circ} \mathrm{F}\left(816^{\circ} \mathrm{C}\right)$ and at flue gas temperatures of $2500^{\circ} \mathrm{F}\left(1371^{\circ} \mathrm{C}\right)$, the 310 stainless steel, nickel, and Inconel samples were campletely destroyed by the seeded gas. Haynes 25 , although slightly attacked, would probably yield satisfactory service under the existing conditions.

No corrosion at $11000^{\circ} \mathrm{F}\left(593^{\circ} \mathrm{C}\right.$ ) metal temperature, in a $2100^{\circ} \mathrm{F}\left(1149^{\circ} \mathrm{C}\right.$ ) seeded flue gas, was found with 310,316 and 406 stainless steels. However, 406 stainless steel was severely attacked in both the seeded and unseeded flue gas.

Both carbon steel and Croloy 5 were attacked at metal temperatures of $800^{\circ} \mathrm{F}\left(427^{\circ} \mathrm{C}\right)$ in a $1800^{\circ} \mathrm{F}\left(982^{\circ} \mathrm{C}\right)$ flue gas. It was concluded, though, that Croloy $2 \frac{3}{4}$ might fulfill short term use for these conditions.

Corrosion specimens of 310 stainiess steel, Inconel, and nickel, exposed to $2500^{\circ} \mathrm{F}\left(1371^{\circ} \mathrm{C}\right)$ unseeded flue gas, were renoved and weighed after 83 hours. Weight loss was directly proportional to the nickel content, the maximum being $14 \%$ for nickel and the minirmm being $1 \%$ for the 310 stainless steel. Although the average diameter of the Inconel sample remained constant, the sample was furrowed and suffered a $9 \%$ weight loss. Electron-beam microprobe analysis revealed sulfur attack at the alloy grain boundaries. Sulfur-nickel reactims mmpar to increase the grain size and cause increased metal loss; the addition of alkali increases the corrosion rates.

It is apparent that the need exists for considerably more research in the area of metal corrosion under MHD conditions. The investigations carried out to date have been fragmentary and of relatively short duration. The studies of the British and Hals, et al., while offering some insight into potential problems, are not truly representative of coal-fired MHD conditions. The work of the Bureau of Mines, although simulating the MHD enviroment more closely, was limited in scope. Questions to be resolved include the effect of reduced air operation on corrosion, the enhanced destructive effects of an alkali-sulfur containing flue gas, the role of $\mathrm{SO}_{3}$, alkali trisulfates and molten sulfates in metal wastage reactions, and the development of corrosion control methods.

The steam bottoming plant and metallic heat exchangers represent key components in the successful development of MHD combined cycle power generation. Only a greatly expanded research effort will elucidate the solutions to corrosion related problens involving these components.

\section{Deposits}

$\therefore \quad$ As previously indicated, the presence of solid deposits on heat transfer and refractory surfaces is a serious concern. Where and to what degree such deposits occur will have a substantial impact on corrosion, seed recovery, heat transfer, and equipment maintenance. 
There is only a limited amount of evidence available from MHD experiments to date. Mawatari, et al. (14) studied seed deposition in metal shelland- tube recuperative air heaters. In one series of experiments, kerosine was burned with preheated air and seeding was accomplished by injection of powdered $\mathrm{K}_{2} \mathrm{SO}_{4}$ or methanol solutions of $\mathrm{KOH}$. Potassium concentrations in the working fluid ranged from 0.1 to $1 \mathrm{wt}-\%$.

It was found that as long as the gas temperature was maintained above the melting point of the seed material, deposition in the air heaters was moderate. Even though the metal surfaces were at temperatures below the melting point, the deposits were of limited thickness since the surface of the deposit was molten. The thickness of the layer was about $3 \mathrm{~mm}$.

In experiments were the gas temperatures were below the seed melting point, seed deposition was so severe as to nearly block the gas passages completely. The system could only be operated for short periods because of the rapid pressure build-up in the air heaters.

To overcome the seed deposition problems, a mechanical seed removal device was used. This device was simply a scraper that was operated intermittently. The periodic removal of deposits from tube surfaces permitted long term, steady-state operation of the system. However, it was necessary to water cool the seed removal device which resulted in considerabie heat losses. Then it was net cuiled, sticky deposits fomed on the device itself which were difficult to remove completely.

The Bureau of Mines has accumulated relevant experience with such deposits in their coal-fired combustor test facility. Following conbustion, the MHD exhaust gas, passes through in succession an MgO brick chimey, an aircooled Haynes 25 alloy heat exchanger, an MgO refractory crossover section, two air-cooled stainless steel heat exchangers, an air-cooled-carbon steel heat exchanger, and a set of baghouse filters. This system is depicted in Fig. 6, together with the approximate temperature levels existing in each section. This heat recovery system spans a temperature range of $350^{\circ} \mathrm{F}$ $\left(177{ }^{\circ} \mathrm{C}\right)$ to $4000^{\circ} \mathrm{F}\left(2204^{\circ} \mathrm{C}\right)$, and includes a number of pieces of equiprient which undoubtedly will be encountered in an actual MHD steam-bottoming plant.

This system was run for several hundred hours under a wide range of operating conditions: fuels such as gas and coal, oxidizing and reducing conditions, together with a number of different seeding conpounds and seeding levels. Thus, the deposits produced do not typify one definite operating condition, but a composite of many different operating conditions. When this system was disassembled to make way for a new system, several interesting observations were made. First, the MgO bricks in the high-temperature chinmey were hardly attacked, except for a reddish deposit on the outside of the bricks'. Fig. 7 is a picture which shows the outer surface and the inner crosssection of a typical brick. 
Evidently, the temperanures were so high that a corrosive seed phase which could penetrate the bricks was absent. In addicion, the fact that approximately $70 \%$ of the coal ash was rejected as slag in the MHD cyclone combustor may also have inhibited attack here. This encorraging result indicates that, at gas temperatures similar to those anticipated in the hightemperature MHD air preheater section, seed-slag blockage and attack may be preventable by careful design.

At the hot end of the Haynes 25 heat exchanger, pitting ensured on exposure to the $3000^{\circ} \mathrm{F}\left(1649^{\circ} \mathrm{C}\right)$ flue gas, while at the cold end no corrosion occurred on exposure to $2000^{\circ} \mathrm{F}\left(1093^{\circ} \mathrm{C}\right.$ ) flue gas. In sinarp contrast to these conditions, profuse solid deposits formed on the wall of the uncooled refractory-lined crossover section. One such deposit is shown in Fig. 8. Interestingly enough, these heavy deposits caused no apparent damage to the refractory.

Same minor deposits were noted in the stainless-steel coglers, but again no damage was experienced at a wall terperature of $500^{\circ} \mathrm{F}\left(260^{\circ} \mathrm{C}\right)$. The flaking of these deposits led to the plugging of several of the 1-3/4" carbon steel tubes in the final air-cooled heat exchanger beneath the stainless steel coolers. Fig. 9 shows the fouling and blockage of a number of tubes. Narrow passages and small tubes should obviously be avoided.

Surprisingly, no sticky, glass-itike depocits, characteristic of the formation of a molten seed phase were reported. Frou live powieif arranrmno of the deposits, it is perhaps possible that these deposits may have formed as a fine solid/liquid fume or mist impinging on the tube surface.

\section{Seed Recovery}

The MHD seed must be collected, recovered in a relatively pure form, regenerated to reduce its sulfur content, and recycled to the combustor. MHD seed losses beyond 2-5\% have been generally deemed to be economically nonviable $(2,13)$. The magnitude of this permissible seed loss depends on the price of potassium salts and coal, both of which have been rising dramatically of late.

Wall deposits in an MHD system can be blown off using air or steam as in conventional boiler practice, provided the deposits are not of the adherent glass-1ike variety. Special techiques would then be required. The seed-ash residue is either collected directly from each process unit or blown through the plant to appropriate dust collection equipment. Erploying a baghouse filter, the USBM obtained a particulate collection efficiency of approximately 99.5\%. The British, Japanese, and Avico have reported successful operation with electrostatic precipitators $(7,10)$. 
The particulates collected in the USBM system had a distribution of sizes in which about 90\% (by wt) fell between 1 and 5 microns in diameter ( 1 ). This is an order of magnitude smaller than the fly ash from a conventional coalfired power plant and should be borne in mind when selecting gas clean-up equipment. A typical photograph of such a fly ash collected in an unseeded num in the USBif experimental apparatus is shown in Fig. 10. Various combinations of gas-clean-up devices, such as mechanical cyclones, Venturi scrubbers, baghouse filters, and electrostatic precipitators could be tested.

Spent MHD seed leaving the plant will be_either associated with the fly ash or the frozen coal slag. That portion associated with the slag is chenically locked into the frozen slag, and the chances of economic recovery are remote. On the other hand, fly ash-seed mixtures are amenable to treatment. The collected fly ash-seed mixture is initially subjected to a hot water extraction step in which two fractions result--a concentrated extract of soluble potassium salts and insoluble potassium-containing fly ash residue. The filtrate is fed to a vacum crystallizer for water removal. The recovered potassium is collected and stored in lock hoppers. The insoluble residue can be recycled or discarded, depending on the fraction of potassium in it. The USBM seed recovery-sulfur removal system is shown in Fig. 11. For the purposes of simplicity, we have assumed the primary salt produced to be potassium sulfate, although other salts of potassium are undoubtedly present.

Raman spectra stüites ibive disciosed the existence of water-unextractable potassium alumina silicate compounds interspersed in the fly ash. It has also been established experimentally that the level of seed extractability is directly proportional to the efficiency of slag removal from the MHD combustor. Potassium recoveries exceeding $99 \%$ were obtained for simulated slag rejections above $90 \%$ (2). This tends to accentuate the importance of clean combustion.

Losses of seed can take place in two ways: either as a-direct loss to the MHD slag or as part of the unextractable seed-fly ash residue. Both possibilities should be minimized as much as is technically feasible. All of the steps outlined here are accepted unit operations, but they must be checked out on a reasonable scale prior to implementation.

Seed Regeneration

The Bureau of Mines has shown in earlier experimental work that open-cycle MHD has a self-contained sulfur removal system $(2,4)$. The MHD seed itself. is present in sufficient quiantities to capture the sulfur contained in most American coals. In fact, $\mathrm{SO}_{2}$ levels as $\mathrm{low}_{\text {as }}$ that of natural gas combustion are achievable provided sufficient quantities of seed are added.

However, for this process to succeed, the seed regeneration step is a pivotal one. The sulfur-bearing spent seed must be regenerated to proctuce a partially sulfur-free seed, prior to being recycled back to the combustor. Earlier work has described some of the kinetics of the relevant reactions (8). The seed regeneration reaction proceeds at $1472^{\circ} \mathrm{F}\left(300^{\circ} \mathrm{C}\right)$ and essentially at atmospheric pressure. The kind of reactor to be adopted will be deternined as part of the scale-up procedure. 
The spent seed, rich in $\mathrm{K}_{2} \mathrm{SO}_{4}$, reacts with a hot reducing gas mixture regenerating a partly sulfur-free seed and liberating gaseous $\mathrm{H}_{2} \mathrm{~S}$. $\mathrm{H}_{2}$-steam, synthesis gas-steam, producer gas-steam are likely candidates for the reducing gas. If other potassium-sulfur compounds containing less oxygen such as $\mathrm{K}_{2} \mathrm{~S}$ or $\mathrm{KHSO}_{3}$ are present, the energy and capital requirements for desulfurization will be correspondingly reduced. Enough sulfur is removed from the spent seed to balance the sulfur contained in the original coal. This leads to the canplete elimination of $\mathrm{SO}_{2}$ fram the products of coal cambustion.

The $\mathrm{H}_{2} \mathrm{~S}$ from the gases leaving the regeneration unit is recovered in a separate gas purification step using available absorption techology, and is then sent to a Claus unit for conversion to elemental sulfur. The partially desulfurized potassium salts, mainly $\mathrm{KOH}$ and $\mathrm{K}_{2} \mathrm{OO}_{3}$ are retumed to the $\mathrm{MHD}$ combustor as fresh seed. Some rather comprehensive rate data has been recently obtained on the regeneration of spent seed and will be published shortly.

As far as materials are concerned, the desulfurization reactor tube was made from a $99.8 \%$ dense fine-grained alumina. A photograph of this reactor is shown in Fig. 12. This reactor has managed to withstand the action of molten potassium salts for hundreds of hours of operation. These favorable results further confin the work of Kellogg and the University of Utah, with regard to gasifier vessel linings and air preheater refractories $(5,6)$. Thus,

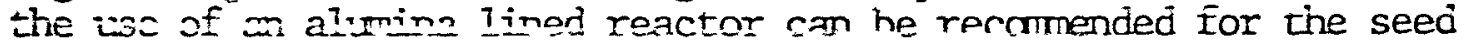
regeneration step.

\section{Conclusions}

The state of knowledge regarding the design of the MHD heat recovery and seed recovery systen for a coal-fired plant leaves a great deal to be desired. The scientific basis for design has been inproved somewnat through recent research. However, the prime deficiency remains; namely, a lack of hard experimental data on materials and components for coal-fired systems under simulated central-station power plant conditions. No definitive design study has ever been performed on the layout of a steam bottaming plant, while only a preliminary design has been prepared for the seed recovery-sulfir removal system (2). Hopefully, with increased funding and the construction of a pilot plant, these deficiencies will be remedied in the immediate future.

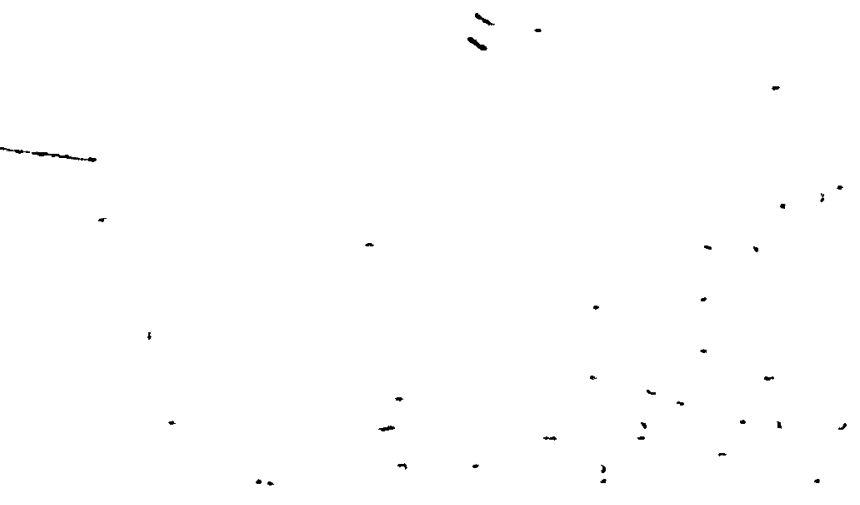




\section{References}

1. Bienstock, D., P.D. Bergman, J.M. Henry, R.J. Denski, J.J. Demeter, and K.D. Plants. Magnetohydrodynamics--Low Air Pollution Power Generation. Presented at Winter Annual Meeting, ASME, Nov. 11-15, 1973, Detroit, Mich. Paper No. 73-WA/Ener.-3, 12 pp.

2. Bienstock, D., P.D. Bergman, J.M. Henry, R.J. Demski, J.J. Deneter, and K.D. Plants. Air Pollution Aspects of MHD Power Generation. Presented at 13th Symposium on Engrng. Aspects of MHD, Stanford Univ., Mar. 26-28, 1973, pp. VII.1-VII.1.10.

3. Bienstock, D., R.J. Demski, and R.C. Corey. Corrosion of Heat Exchange Tubes in a Simulated Coal-Fired MHD System. Trans. ASME, J. Eng. for Power, 93, Series A, No. 2, April 1971, pp. 249-256.

4. Bienstock, D., R.J. Denski, and J.J. Demeter. Environmental Aspects of MHD Power Generation. Presented at 1971 Intersociety Energy Conversion Engrng. Conf., Aug. 3-6, 1971, Boston, Mass. Publ. in Conference Proc., pp. 1210-1217 by Society of Automotive Engineers, Inc., New York, N.Y.

5. Callister, W.D., Jr., M. Fishler, I.B. Cutler and R.W. Ure, Jr. Corrosion of MHD Preheater Materials in Coal Slag-Seed Mixtures. 14th

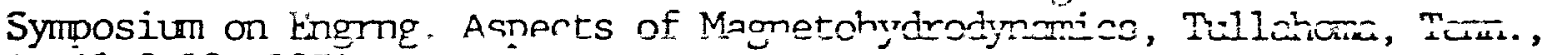
April 8-10, 1974.

6. Cover, A.E., W.C. Schreiner, and G.T. Skaperdas. Evaluation of Kellogg Coal Gasification Process. Energy Digest, March, 1973, pp. 2-6.

7. EIL Mark VI Research Group. Construction of a Small-Scale MHD Test Plant (EIL Mark VI). 13th Symposium on Engming. Aspects of Magnetohydrodynamics, Stanford Univ., Mar. 26-28, 1973.

8. Feldmann, H.F., W.H. Simons, J.J. Gallagher, and D. Bienstock. Kinetics of Recovering Sulfur from the Spent Seed in an MHD Power Plant. Environmental Science and Tech , 4, (6), Pp. 496-502, 1970.

9. Goubeau, J., H. Kolb, and H.G. Krall. The System Potassium SulfatePotassium Sulfide. Zeitschrift fur Anorganische und Allgeneine Chenie, 236, 1938, pp. 45-56.

10. Hals, F., L. Keefe, and A. E1 Bindari. Studies of Seed Recovery and Corrosion in Coal Fired MHD Power Plants. Presented at Winter Annual Meeting, ASME, Nov. 29-Dec. 4, 1964, New York, N.Y., Paper No. 64-AA/Ener. -5 . 
11. Heywood, J.B. and G.J. Wanack, Eds. Open-Cycle MHD Power Generation. Pergamon Press, London, 1969.

12. Hottel, H.C. and J.B. Howard. New Energy Technology: Some Facts and Assessments. Massachusetts Institute of Technology, 1971, pp. 284-289.

13. Louis, J.F. (Ed.). Open-Cycle Coal Bunning 1MD Power Generation: An Assessment and a Plan for Action. Report prepared for Office of Coal Research by Massachusetts Institute of Technology, Cambridge, llass., Jume, 1971, pp. 98-99.

14. Mawatari, K., M. Kata, N. Inai, and T. Tamaoki. Experiments on Tuirular Heat Exchangers for an MHD Power Plant. 5th International Conf. on MHD Electrical Power Generation, Which, Germany, April 19-23, 1971, pp. 503-518.

15. Michel, J.R. and L.S. Wilcoxson. Ash Deposits on Boiler Surfaces from Burning Central Illinois Coal. ASME Paper No. 55-A-95, Chicago, Ill. Nov. 1955.

16. Mount, C.L., G.C. Wiedersum. Gas-Side Corrosion in Coal and Oil-Fired Utility Units. Presented at IFEE-ASME INational Power Conference, Tulsa, Okla., Sept. 27-Oct. 1, 1964. Paper IJo. 64-PWR-14.

17. Ovechkin, E.K., et al, Potassium Sulfiâe-Putassiuru Carzanste System. Zh. Neorg. Khim., 19, No. 4, 1974, pp. 1058-1059.

18. Pepper, J.W., R.H. Eustis, and C.H. Kruger. ND Concentrations in MH Steam Power Plant Systens. 14th Symposium Engmg Aspects of Magnetohydrodynamics, Tullahana, Term., April 3-10, 1974.

19. Reid, William T. External Corrosion and Deposits. American Elsevier Publishing Company, liew York, 1971.

20. Schneider, S.J., W. Capps, H.P.R. Frederikse, W.R. Hosler, D.A. Kauffman, E.M. Levin, C.L. NicDaniel, T. Negas and E.R. Plante. High Temperature MHD Materials. National Bureau of Standards Information Report 74-543, Washington, D.C., August, 1974.

21. Spencer, F.E., Jr. Talk presented at OCP Contractors Meeting, Tullahoma, Tern., April 11, 1974, to be published.

22. Spencer, F.E., Jr. and A.A. Orning. An Algorithm for Calculating Chenical Equilibrium. U.S. Bureau of Mines Rept. Investigations 7786, $\because \quad 1973$.

23. Weller, A.E. and William T. Reid. The Econonic Position of MD for Central Power. Presented at Winter Annual Meeting, ASiE, Nov. 29-Dec. 4, 1964, New York, N.Y. Paper Ho. 64-WA/Ener.-1.: 
$I$ DIRECTLY FIRED
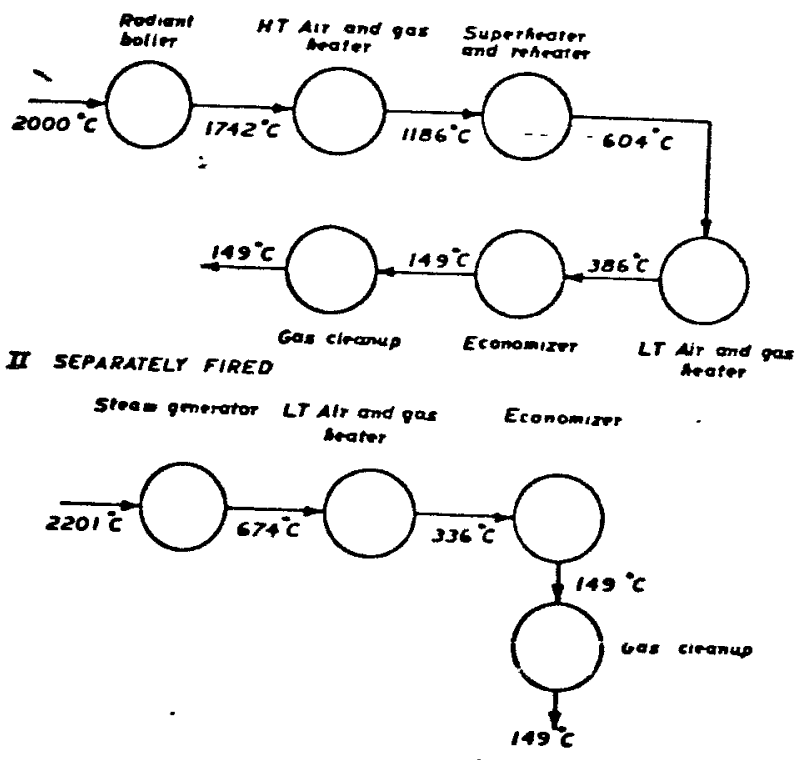

Fig. 1. Temperatures of downstream components for separately and directly fired MHD cycles.

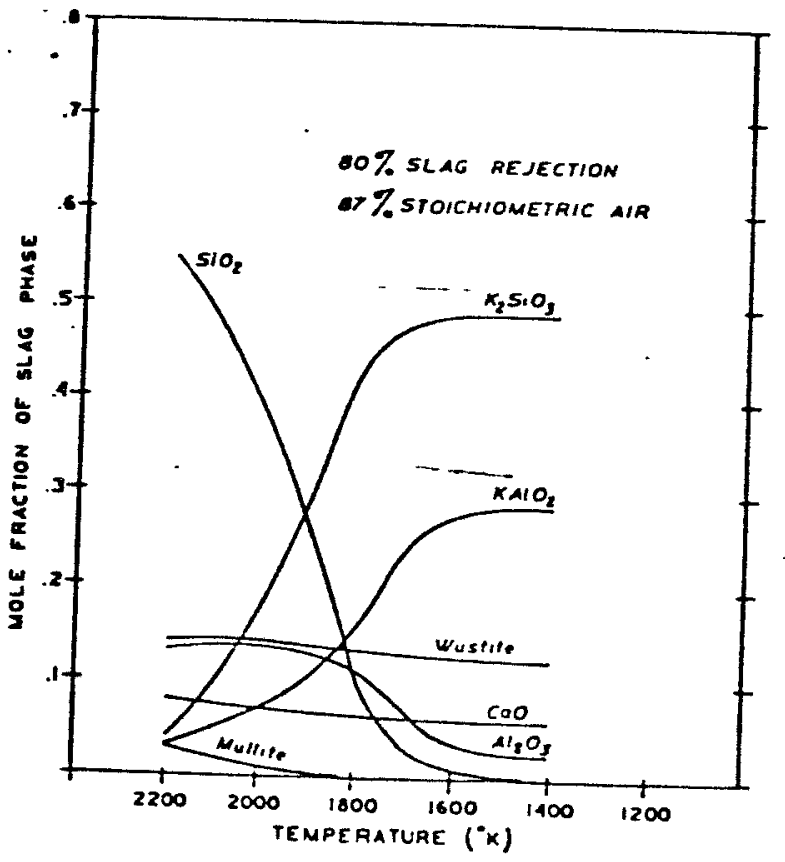

Fig. 2. Equilibrium composition of slag phase as a function of temperature. 


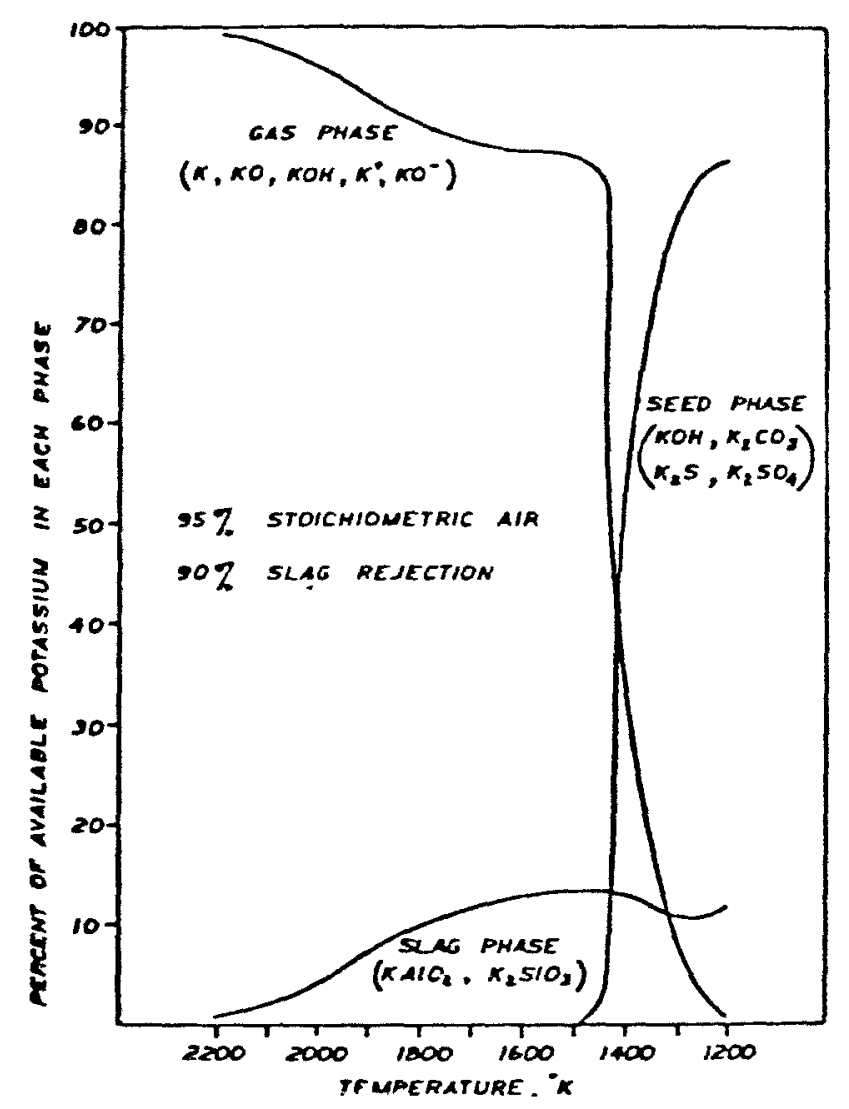

Fig. 3. Equilibrium distribution of potassium between liquid and gas phases as a function of temperature.

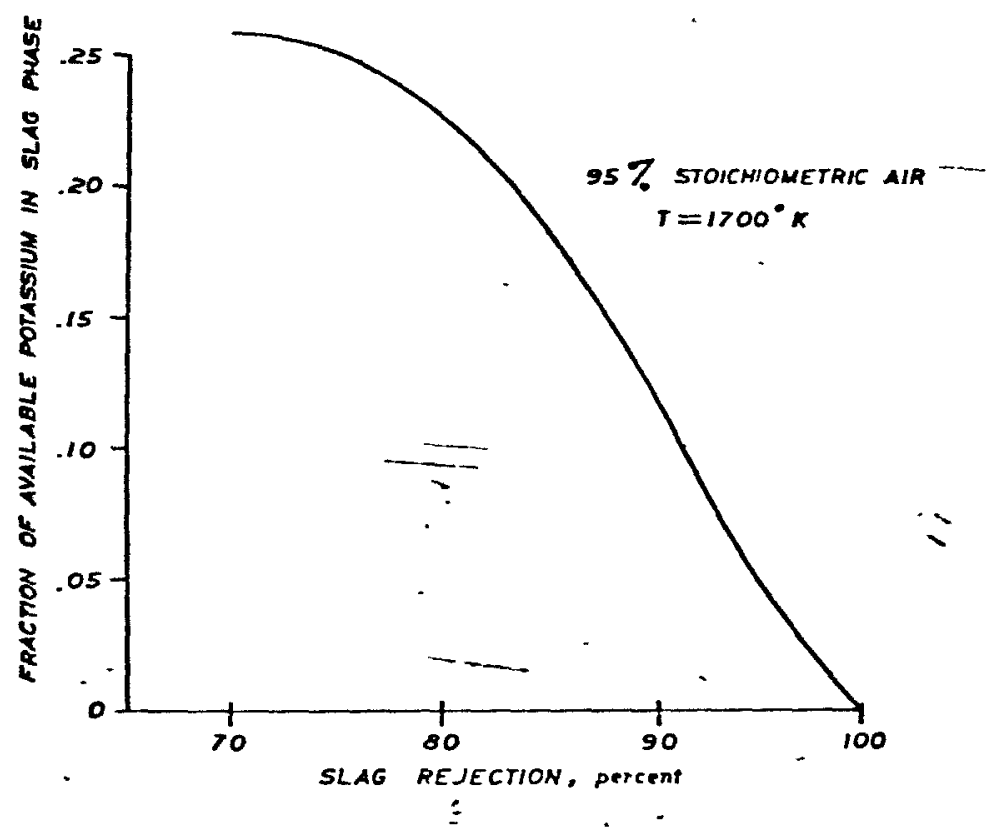

Fig. 4. Fraction of total potassium lost in the slag phase as a function of slag rejection. in the combustor. 


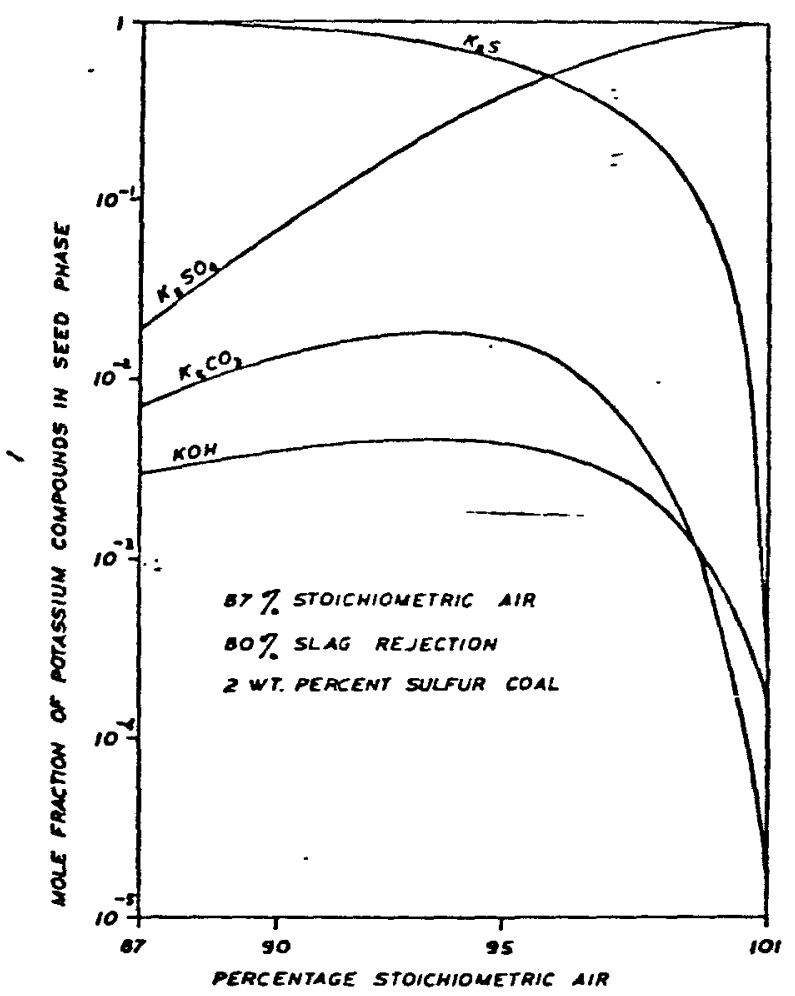

Fig. 5. Effect of fuel to air ralio on equiliorium composition of molten seed phase.

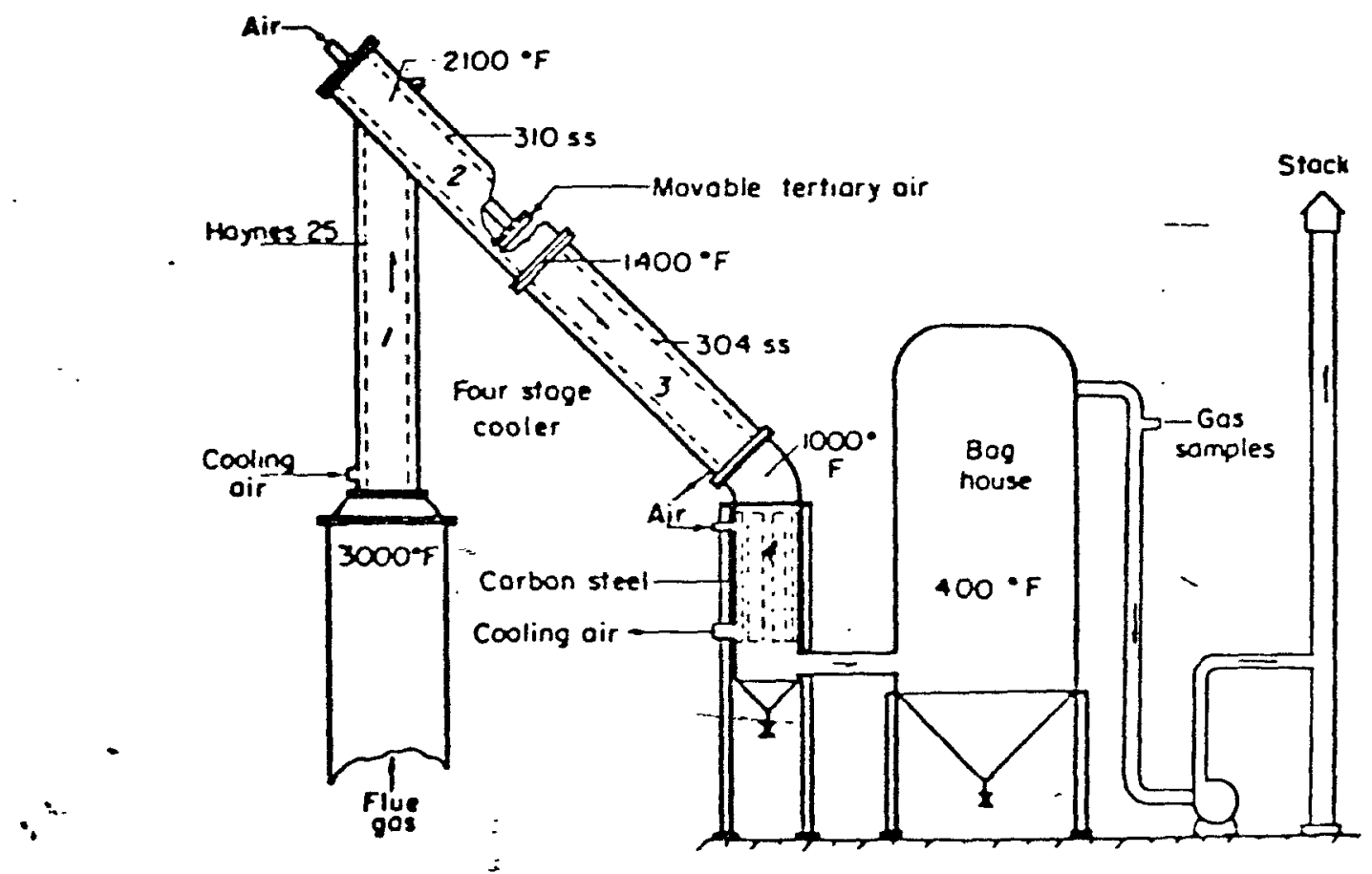

Fig. 6. Heat recovery system for USBM experimental MHD combustor. 


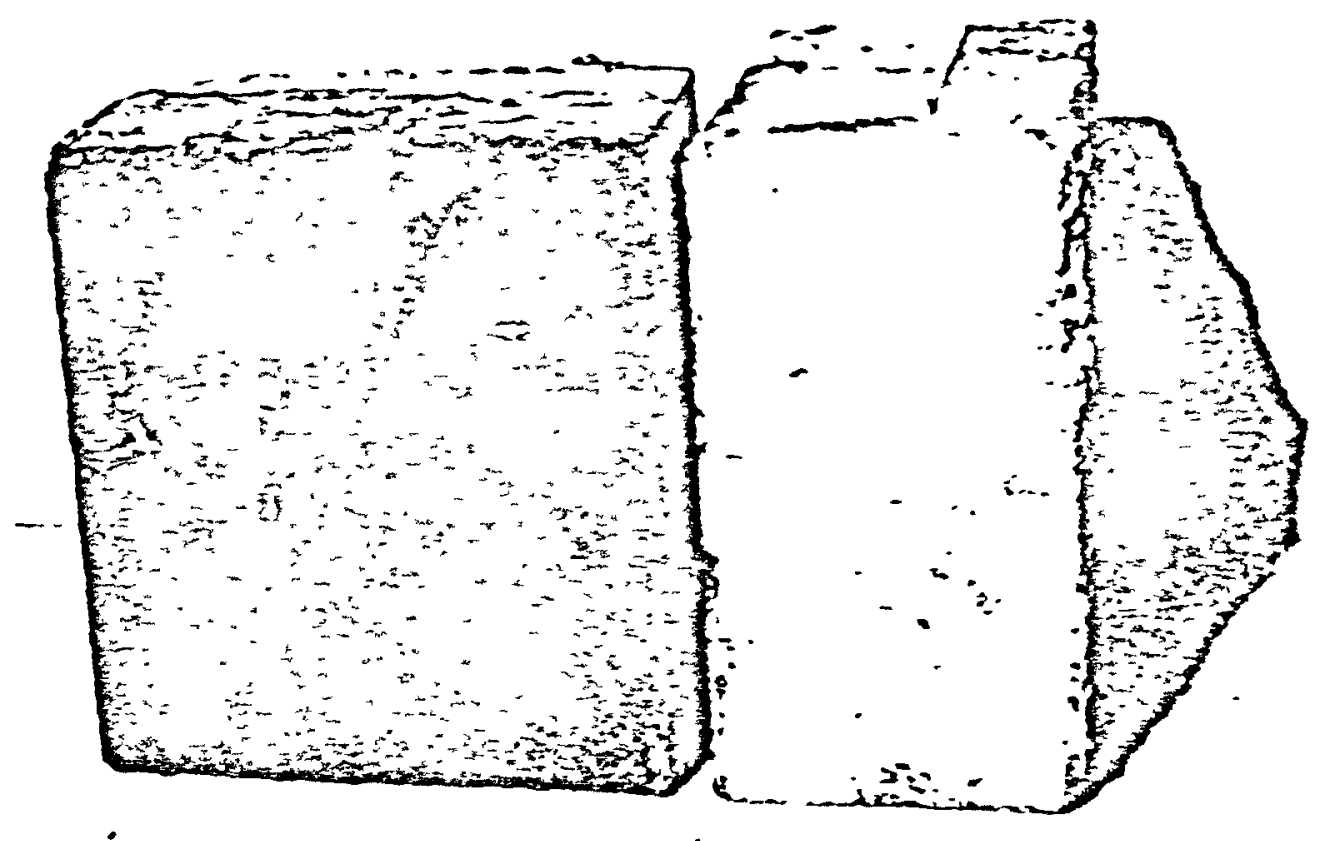

Fig. 7. Magnesia brick after several hundred hours exposure to seeded flue gas.

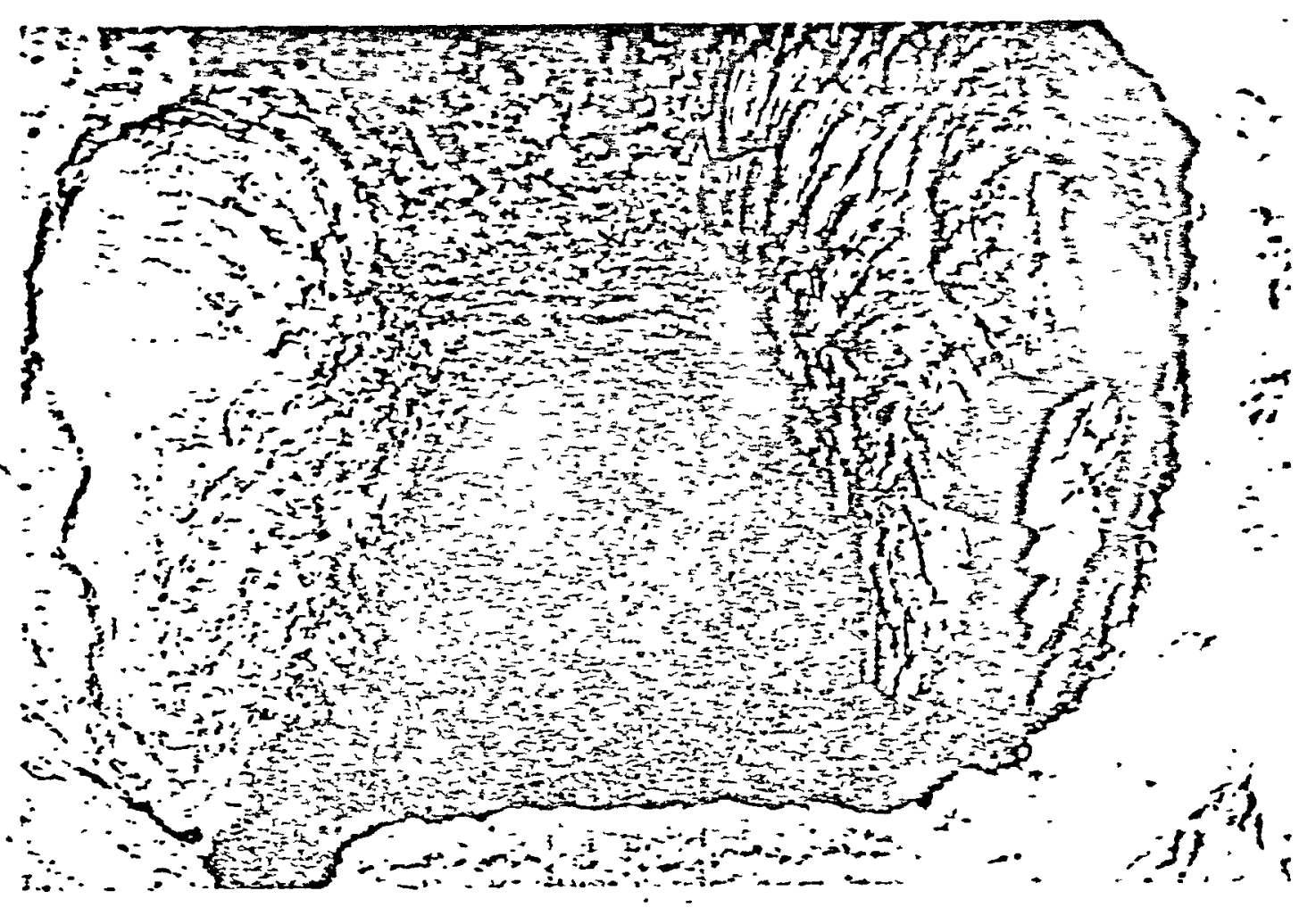

Fig. 8. Wall deposits in refractory-lined section after several hundred hours exposure to seeded flue gas. 


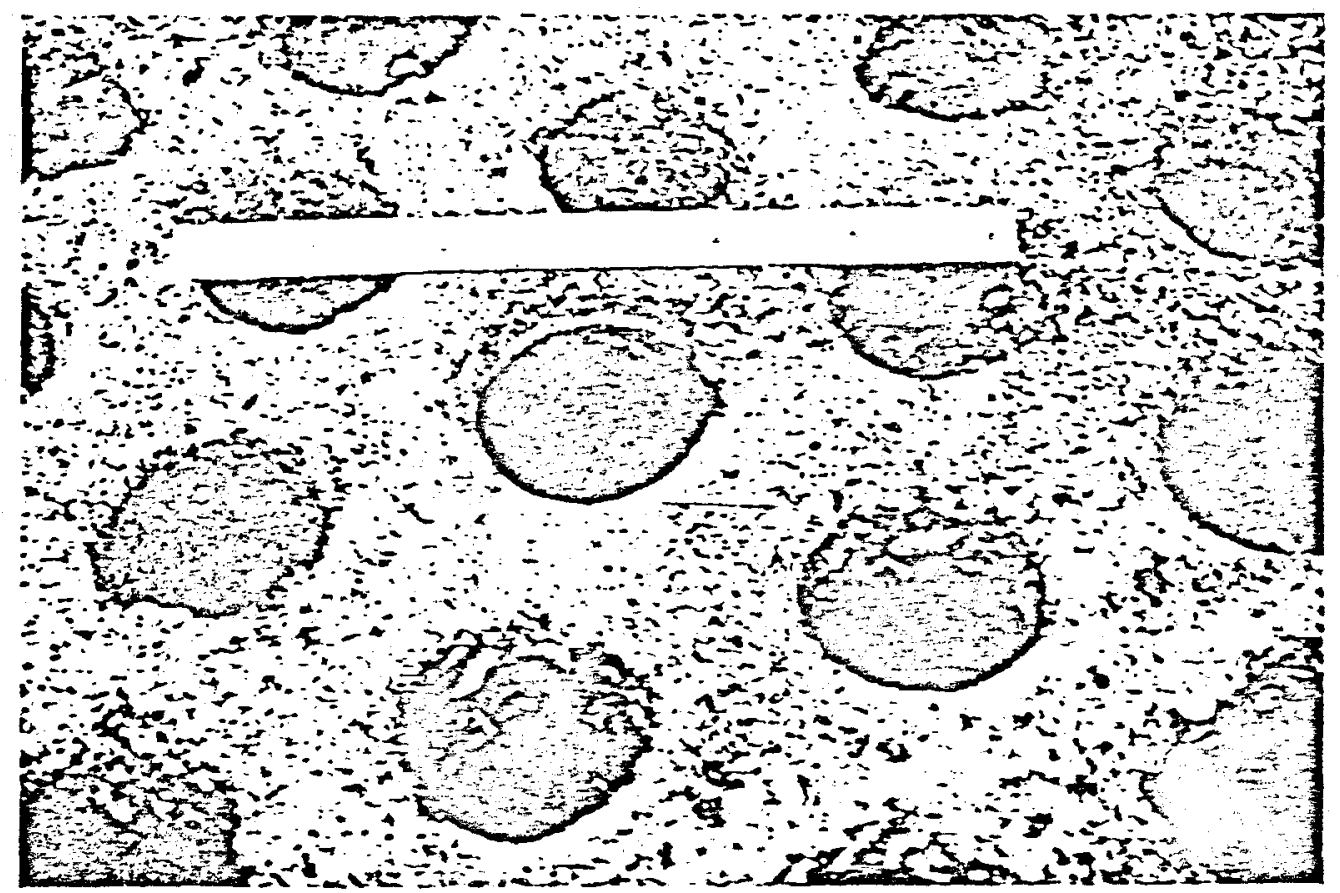

Fig. 9. Blockage of tubes by deposits in carbon steel heat exchanger exposed to MHD combustion gas.

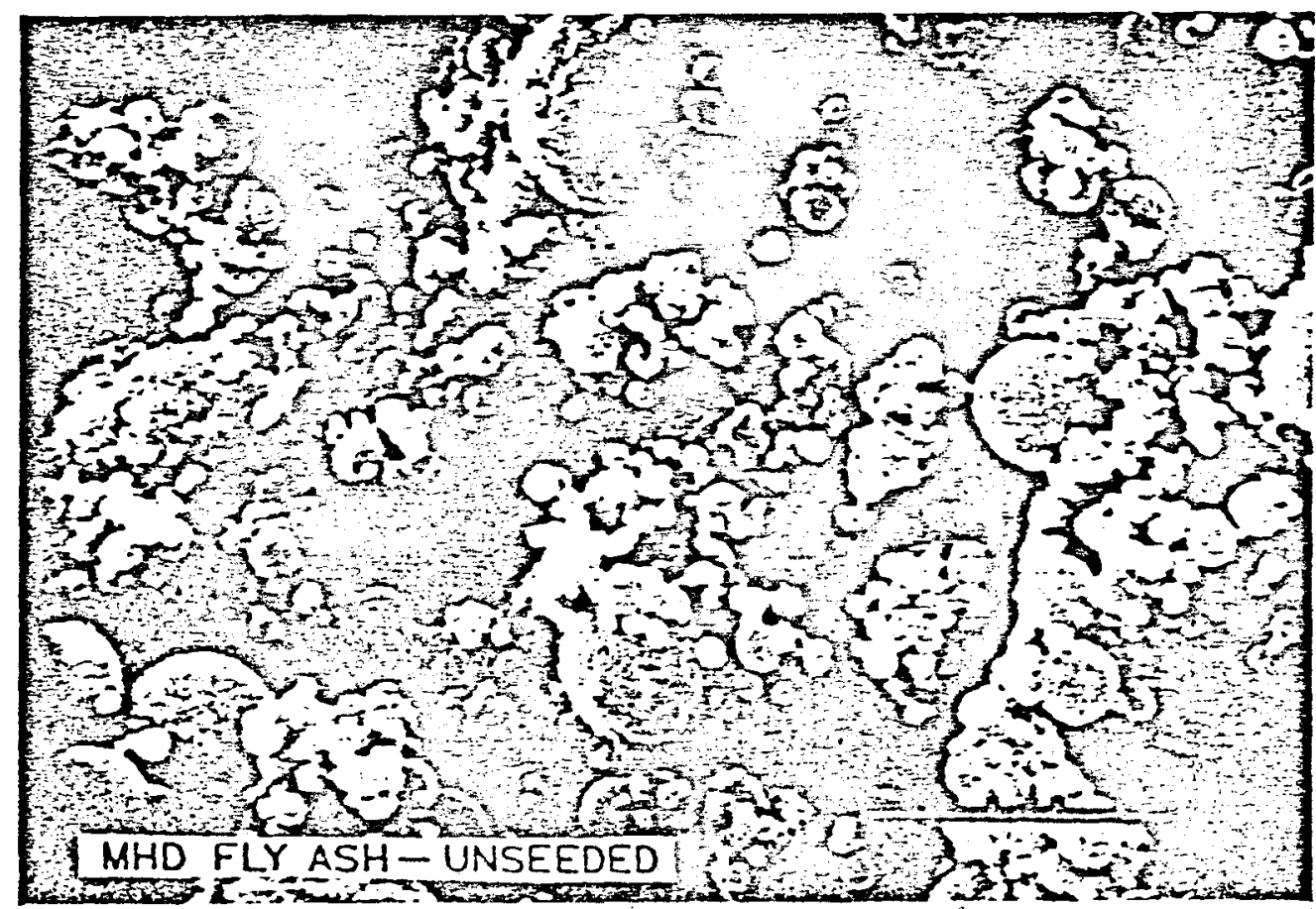
$\because$

Fig. 10. Collected Specimen of unseeded MHD fly ash. 


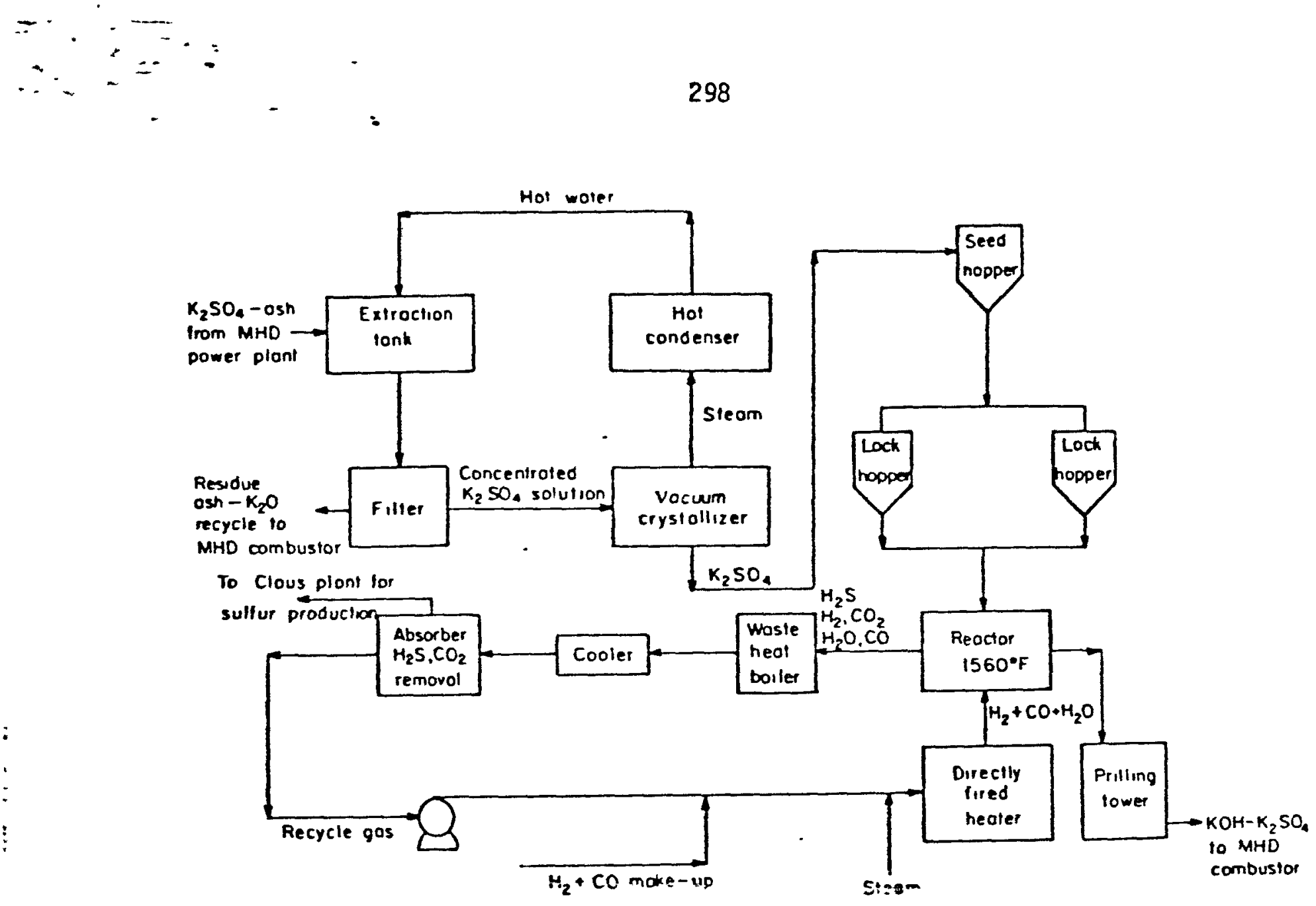

Fig. 11. Seed recovery-sulfur removal system for MHD powerplant.

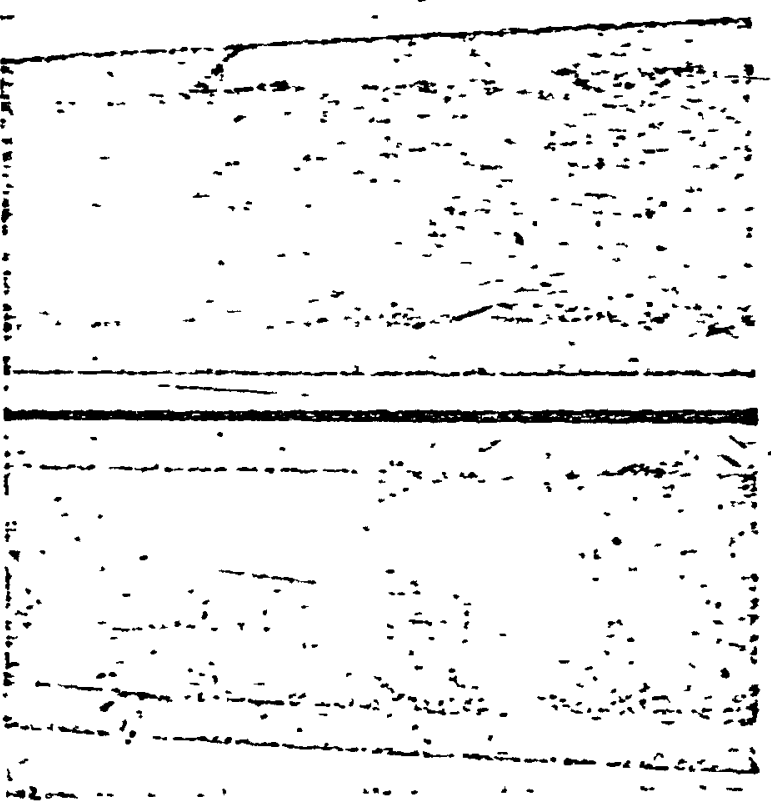

Fig. 12. Alumina reactor tube used in bench scale desulfurization studies after 50 hours of operation. 


\section{Discussion}

Perry Bergman. We need to know the controlling mechanism, thermodynamic or kinetic, for seed-slag interaction so that we can determine what component of the system the bulk of the seed will be collected from.

It would be extremely difficult to say anything about the kinetics of this process. Thermodynamics tells us how bad the problem might be. As I indicated during the talk, the presence of a few $\mathrm{SO}_{2}$ in the combustion gases may limit the concentration of $\mathrm{K}_{2} \mathrm{O}$ dissolved in the slag to about $20 \mathrm{wt} \%$. Rejection of 80-90\% of the slag in the combustor would allow about $95 \%$ seed recovery. In the absence of $\mathrm{SO}_{2}$ the problem appears more difficult. We plan additional experimental work at NBS on these problems.

R. De Saro. Is zero slag rejection unacceptable due to the large seed capture?

I jeileve so.

K. E. Tempelmeyer. Could you comment on the kinetics of seed/ slag absorption process? Is it in your opinion fast or slow and do your experimental $\mathrm{K}_{2} \mathrm{O}$ desorption tests give any evidence about the kinetics of desorption?

Our tests do not give any information about the kinetics of desorption. One could hope that the kinetics was not fast enough to keep the slag and seed at equilibrium.

J. Henry. Let me suggest the following in reference to kinetics being slow enough to result in reduced seed loss in slag capture: (1) Since the USBM experimental results are reasonably well modeled by an equilibrium assumption at a plausible temperature and (2) since the experimental unit had a more severe cooling profile than several suggested full-scale MHD plants, the kinetics of seed capture by slag may not be as slow as is hoped for effective slag separation from seed.

I think this is an important point. When considering an operational MHD unit it may be neither possible nor efficient to suddenly extract enough heat to freeze the equilibrium at some higher temperature. 
A. L. Bement. Will hydrates of silicon be a significant factor under the conditzons existing at various locations in the MHD system? What can you say about the degradation of $\mathrm{SiO}_{2}$-containing refractories in the combustor and preheater based upon your slag-seed reaction studies?

I presume you refer to gaseous $\mathrm{Si}(\mathrm{OH})_{2}$, $\mathrm{Si}(\mathrm{OH})$, or perhaps $\mathrm{H}_{2} \mathrm{SiO}_{3}(\mathrm{c})$. I do not think that any of these materials will be significant. I believe that silica containing refractories should be avoided. In addition, it might be wise to consult phase-equilibrium data for the $\mathrm{K}_{2} \mathrm{O}-\mathrm{SiO}_{2}-\mathrm{H}_{2} \mathrm{O}$ system before considering the use of silica based refractorzes.

S. Way. The problems of injecting, mixing, and recovering seed will be less pronounced at lower seeding levels. Levels of 18 mole fraction of potassium are frequently mentioned. Cycle studies indicate that an acceptable level may be about $0.5 \%$ weight fraction or $0.4 \%$ mole fraction.

Yes, that is true.

M. Jones. What is a particle-gas time track across the chart of $\mathrm{P}_{\mathrm{K}} \cdot \mathrm{P}_{\mathrm{O}_{2}}^{1 / 2}$ versus $\mathrm{T}^{-1}$ ?

I don't know but I would presume that the particle velocity would not be much different than the bulk gas velocity. This will depend on the distance from the nozzle.

F. E. Spencer. What was the $\mathrm{O}_{2}$ pressure in your study? In HW work the $\mathrm{N}_{\mathrm{K}_{2}} \mathrm{O}_{2}$ was not in the $\mathrm{SiO}_{2} / \mathrm{K}_{2} \mathrm{SiO}_{3}$ phase. Was your twoIiquid slide (for $\mathrm{K}_{2} \mathrm{SO}_{4}-\mathrm{slag}$ ) based upon experiment?

The oxygen pressure in equilibrium with $\mathrm{K}_{2} \mathrm{O}-\mathrm{SiO}_{2}$ solution was about $1 / 4$ the $\mathrm{K}$ pressure. In the $\mathrm{HW}$ work, the only condensed phase at equilibrium was the $\mathrm{K}_{2} \mathrm{O}-\mathrm{SiO}_{2}$ solution. The two-liquid slide is based on data of Capps" at NBS and by E. Raask and R. Jessop, Phys. and Chem. of Glasses 7200 (1966). $\because$
$\vdots$
$\vdots$ 